\title{
A Study of the Anatomical Variations in the Position of the Greater Palatine Foramen in Adult Human Skulls and its Clinical Significance
}

\author{
Variaciones Anatómicas en la Posición del Foramen Palatino Mayor \\ en Cráneos Humanos Adultos y su Significación Clínica
}

Mitesh R. Dave*; Vaishali Kiran Yagain** \& Samir Anadkat***

\begin{abstract}
DAVE, M. R.; YAGAIN, V. K. \& ANADKAT, S. A study of the anatomical variations in the position of the greater palatine foramen in adult human skulls and its clinical significance. Int. J. Morphol., 31(2):578-583, 2013.

SUMMARY: Pain is a common distressing symptom in dental practice. Depending upon the cases, different techniques are used to relieve pain. One of these is peripheral trigeminal nerve block. Peripheral trigeminal nerve block anaesthesia has proved to be an effective and convenient way to anaesthetise large regions of oral and maxillofacial complex. This block can be intraoral or extra oral. The intraoral route is through the greater palatine foramen in which the dental surgeons enter into the pterygopalatine fossa, where the maxillary nerve is situated. The morphological variations in the position of greater palatine foramen may be of clinical importance in the administration of local anaesthesia and in palatal surgery. In the present study, the distance of greater palatine foramen from the median palatine suture, and from the posterior border of hard palate have been noted, and the position of greater palatine foramen relative to the maxillary molars, as well as the direction of the foramen have been examined.
\end{abstract}

KEY WORDS: Greater palatine foramen; Peripheral trigeminal nerve block; Pterygopalatine fossa; Maxillary molars.

\section{INTRODUCTION}

The bony palate on the base of the skull is formed by the alveolar arch and the hard palate. Alveolar arch bears the sockets for the roots of the upper (maxillary) teeth. Medial to the third molar tooth on either side is the greater palatine foramen, between the horizontal plate of palatine bone and the palatine process of maxilla. Further back are small multiple lesser palatine foramina in the pyramidal process of the palatine bone. Through the corresponding palatine foramina pass the greater and lesser palatine nerves and vessels (Sinnatamby, 1999). The greater palatine nerve is a branch of maxillary nerve, which is the second division of trigeminal nerve. It starts in the middle of the trigeminal ganglion and leaves the skull through foramen rotundum. Then it enters the pterygopalatine fossa. In this fossa it gives a number of branches and itself continues as infraorbital nerve. The greater palatine artery is a branch of third part of the maxillary artery in the pterygopalatine fossa. It accompanies the greater palatine nerve in the greater palatine canal. Here it gives two or three lesser palatine arteries, which transmit through the lesser palatine foramina. Greater palatine artery emerges through the greater palatine foramen on the hard palate with the greater palatine nerve. Then it runs forwards in a groove to the incisive canal and anastomoses with a branch of sphenopalatine artery. The greater palatine nerve innervates the gums, mucous membrane and palatine glands of the roof of the mouth.

\section{MATERIAL AND METHOD}

The present study was conducted with the aim to ascertain the position of the greater palatine foramen in relation with various landmarks in male and female skulls. The study material comprised of 100 dry, sexed, adult human skulls from sources in the various Medical Colleges of Gujarat, India. Out of 100 skulls, 60 were males, 39 were females, and 1 unknown sex.

\footnotetext{
* Assistant Professor of Anatomy, GMERS Medical College, Valsad, Gujarat, India.

** Assistant Professor, Department of Anatomy, Medical University of the Americas, Nevis, West Indies.

*** Professor, Department of Anatomy, Medical University of the Americas, Nevis, West Indies.
} 


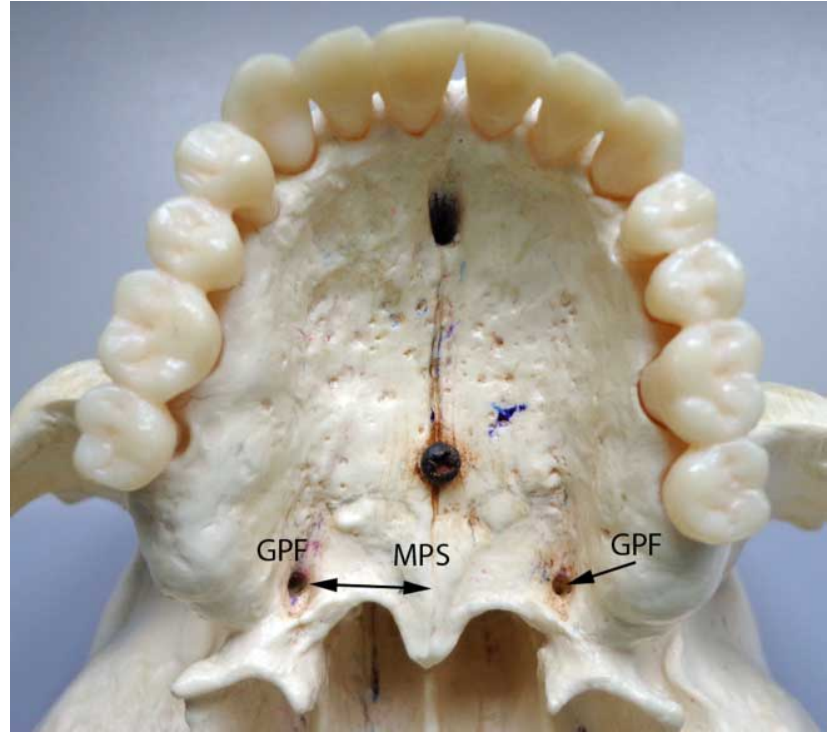

Fig. 1. Illustrates the measurement of distance from greater palatine foramen to Median palatine suture. $(\mathrm{GPF}=$ Greater palatine foramen; MPS= Median palatine suture) .

Sex of the skulls was determined by the following criteria:

Male skull: larger, heavier, more prominent muscular markings especially superciliary arches, external occipital protuberance, nuchal lines, and muscular ridges on mastoid process.

Female skull: relatively smaller, lighter, less prominent muscular markings especially rounded superciliary arches, blunted and rounded external occipital protuberance, less marked nuchal lines, smoother mastoid process.

Keeping in view the aims of the study mentioned above, the following observations were recorded in millimetres, using a pair of Vernier callipers.

Distance between greater palatine foramen and median palatine suture (Fig. 1): the fixed end of calliper compass was placed in the middle of the anterior margin of the foramen, and movable point was placed on the median palatine suture along a line extending medially from the middle of the anterior margin of the foramen and perpendicular to midsagittal plane. The distance between the arm points was then measured to the nearest $0.1 \mathrm{~mm}$.

Distance between greater palatine foramen to the posterior palatal margin (Fig. 2): the fixed end of calliper compass was placed in the middle of the medial margin of the foramen, and movable point was placed posterior to the

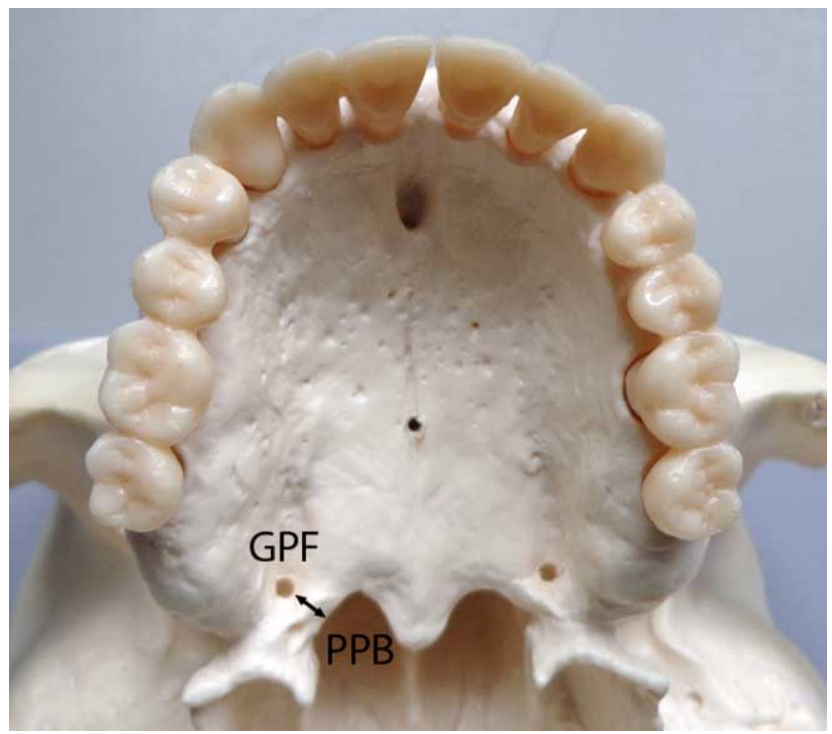

Fig. 2. Illustrates the measurement of distance from greater palatine foramen to Posterior palatal margin. $\mathrm{GPF}=\mathrm{Greater}$ palatine foramen; $\mathrm{PPB}=$ Posterior palatal margin.

foramen on a line represented by a lateral extension of the posterior margin of hard palate. This distance was then recorded to the nearest $0.1 \mathrm{~mm}$.

In order to ascertain the location of the greater palatine foramen in relation to maxillary molars (Figs. 3 and 4): a perpendicular line was drawn from the center of the foramen to midsagittal plane, and was extended towards molars. The point at which this line intersected, the maxillary molar was noted. To find out whether the opening of the foramen is horizontal (anterior) or vertical (inferior), mental probe was used.

For distance of longitudinal palatal grooves, the fixed end of calliper compass was placed in the anterior margin of the greater palatine foramen and the movable point was placed at the anterior distinct end of the groove and distance measured to the nearest $0.1 \mathrm{~mm}$. Also, the tooth level where the groove ended was noted (Fig. 3).

Observations thus made were compiled and tabulated. The following indices were calculated:

Mean value and Standard deviation for the distances of the greater palatine foramen from the median palatine suture, in male and female skulls, were calculated.

Mean value and Standard deviation for the distances of the greater palatine foramen from the posterior margin of hard palate, in male and female skulls, were calculated. 


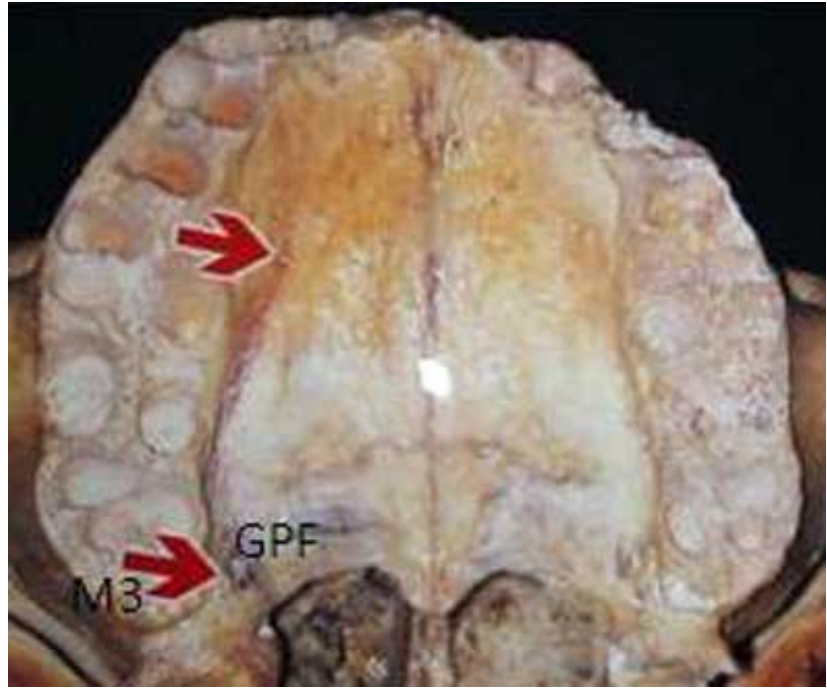

Fig. 3. Illustrates the position of greater palatine foramen medial to the maxillary third molar tooth (lower arrow), and Longitudinal groove (upper arrow). $\mathrm{GPF}=$ Greater palatine foramen; M3= Maxillary third molar tooth.

Further, to test the significance of the differences of observations in different subgroups of study sample in $\mathrm{n}(1)$ and (2), $\mathrm{Z}$ test was used. Following are the confidence limits for $Z$ test: If calculated $Z$ value $<1.96 ; P>0.05=$ Not significant; If calculated $Z$ value $>=1.96 ; P=<0.05=$ Significant; and If calculated $\mathrm{Z}$ value $>=2.56 ; \mathrm{P}=<0.01=$ Highly significant.

\section{RESULTS}

Table I shows that there is no significant difference in the distances between right and left sides of the same type of skulls. But the distances are significant for right sides of the two types of skulls.

Table II shows that there is no significant difference in the distances between right and left sides of the same type of skulls. Further, the differences in distances in the two types of skulls were also not significant.

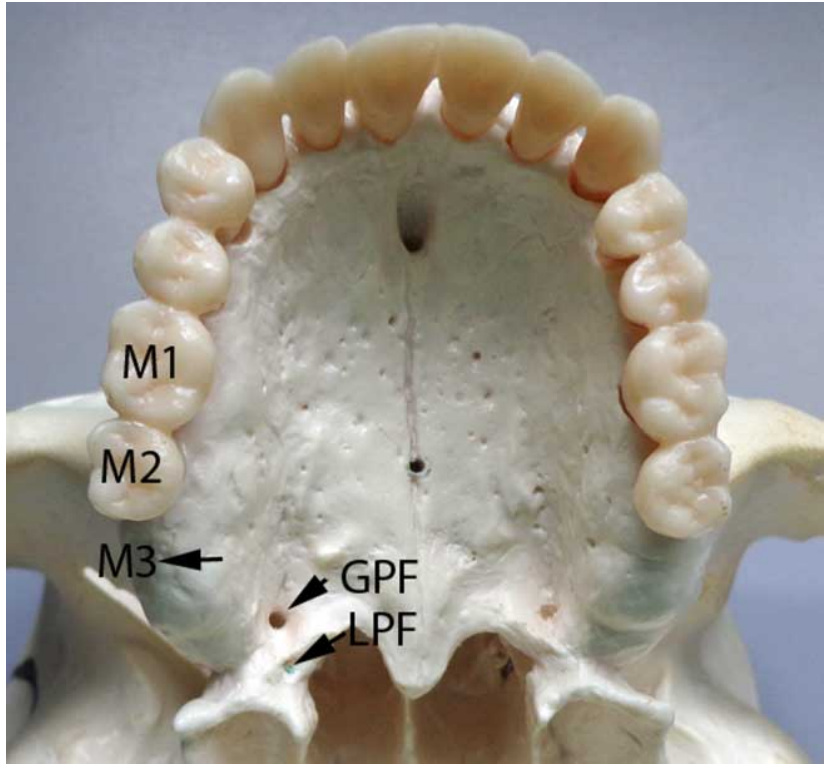

Fig. 4. Illustrates the position of greater palatine foramen behind the maxillary third molar tooth. $\mathrm{GPF}=$ Greater palatine foramen; $\mathrm{LPF}=$ Lesser palatine foramen; M3= Maxillary third molar tooth; M2= Maxillary second molar tooth; M1= Maxillary first molar tooth.

Table III shows the variations in the position of greater palatine foramen relative to the maxillary molars.

In Table IV were evaluated the direction of opening of greater palatine foramen onto the palate in males and females. For longitudinal grooves, mean length of the groove from the anterior margin of greater palatine foramen to its distinct end is $45.08 \mathrm{~mm}$ (Fig 3). $5.5 \%$ of the grooves were divided. The frequency $(\%)$ of the extent of the groove in relation to the tooth level where the groove ended distinctly: a) 1 st maxillary molar $=18.0 \mathrm{~b}$ ) 2nd maxillary premolar $=24.0, \mathrm{c}$ ) Between 2nd maxillary premolar and 1 st premolar $=0.5, \mathrm{~d}) 1$ st maxillary premolar $=27.5$, e) Between 1st maxillary premolar and canine $=$ 7.5 , f) Between maxillary canine and lateral incisor $=2.5$, g) 2nd maxillary molar $=17.5$ and h) 3rd maxillary mo$\operatorname{lar}=2.5$

Table I. Distance $(\mathrm{mm})$ of greater palatine foramen from median palatine suture in males and females.

\begin{tabular}{lcccccc}
\hline \multirow{2}{*}{ Value } & \multicolumn{2}{c}{ Male skulls } & \multicolumn{2}{c}{ Female skulls } & \multicolumn{2}{c}{ Unknown } \\
\cline { 2 - 7 } & Right & Left & Right & Left & Right & Left \\
\hline n of observations & 60 & 60 & 39 & 39 & 1 & 1 \\
Mean distance (mm) & 16.7 & 16.6 & 16.2 & 16.4 & 17.0 & 16.5 \\
SD & 0.112 & 0.109 & 0.116 & 0.110 & ---- & ---- \\
\hline
\end{tabular}

Difference in distances a) Right and Left sides of male skulls: Not significant ( $\mathrm{P}=0.62)$, b) Right and Left sides of female skulls: Not significant $(\mathrm{P}=0.45)$, c) Right sides of male and female skulls: Significant $(\mathrm{P}=0.038)$ and $\mathrm{d})$ Left sides of male and female skulls: Not significant $(\mathrm{P}=0.37)$. 
DAVE, M. R.; YAGAIN, V. K. \& ANADKAT, S. A study of the anatomical variations in the position of the greater palatine foramen in adult human skulls and its clinical significance. Int. J. Morphol., 31(2):578-583, 2013.

Table II. Distance ( $\mathrm{mm}$ ) of greater palatine foramen from posterior margin of hard palate in males and females.

\begin{tabular}{lcccccc}
\hline Value & \multicolumn{2}{c}{ Male skulls } & \multicolumn{2}{c}{ Female skulls } & \multicolumn{2}{c}{ Unknown } \\
\cline { 2 - 7 } & Right & Left & Right & Left & Right & Left \\
\hline n of observations & 60 & 60 & 39 & 39 & 1 & 1 \\
Mean distance (mm) & 6.9 & 6.9 & 6.8 & 7.0 & 6.5 & 6.0 \\
SD & 0.133 & 0.119 & 0.116 & 0.128 & ---- & ---- \\
\hline
\end{tabular}

Statistical interpretation - Difference in distances: 1. Right and Left sides of male skulls: Not significant $(\mathrm{P}=0.66)$, 2. Right and Left sides of female skulls: Not significant $(\mathrm{P}=0.47), 3$. Right sides of male and female skulls: Not significant $(\mathrm{P}=0.71)$ and 4. Left sides of male and female skulls: Not significant $(\mathrm{P}=0.69)$.

Table III. Variations in the position of greater palatine foramen relative to the maxillary molars.

\begin{tabular}{|c|c|c|c|c|c|c|c|c|c|c|c|c|}
\hline \multirow[t]{3}{*}{ Teeth } & \multicolumn{4}{|c|}{ Male skulls (60) } & \multicolumn{4}{|c|}{ Female skulls (39) } & \multicolumn{2}{|c|}{ Unknown (1) } & \multicolumn{2}{|c|}{ Total } \\
\hline & \multicolumn{2}{|c|}{ Right GPF } & \multicolumn{2}{|c|}{ Left GPF } & \multicolumn{2}{|c|}{ Right GPF } & \multicolumn{2}{|c|}{ Left GPF } & \multirow{2}{*}{$\begin{array}{c}\text { Right } \\
\mathbf{n}\end{array}$} & \multirow{2}{*}{$\begin{array}{c}\text { Left } \\
n\end{array}$} & \multirow[b]{2}{*}{$\mathbf{n}$} & \multirow[b]{2}{*}{$\%$} \\
\hline & $\mathbf{n}$ & $\%$ & $\mathbf{n}$ & $\%$ & $\mathbf{n}$ & $\%$ & $\mathbf{n}$ & $\%$ & & & & \\
\hline M4 & 6 & 10 & 2 & 3.3 & 6 & 15.4 & 2 & 5.1 & --- & --- & 16 & 8.0 \\
\hline M3 & 51 & 85 & 57 & 95 & 29 & 74.4 & 36 & 92.3 & 1 & 1 & 175 & 87.5 \\
\hline$M^{*}$ & 3 & 5 & 1 & 1.7 & 3 & 7.6 & --- & --- & --- & --- & 7 & 3.5 \\
\hline M2 & --- & --- & --- & --- & 1 & 2.6 & 1 & 2.6 & --- & --- & 2 & 1.0 \\
\hline
\end{tabular}

Abbreviations: $\mathrm{GPF}=\mathrm{Greater}$ palatine foramen; $\mathrm{M} 4=$ Behind third molar; $\mathrm{M} 3=$ Medial to third molar; $\mathrm{M}^{*}=$ Between second and third molar; M2=Medial to second molar.

Table IV. Direction of opening of greater palatine foramen onto the palate in males and females.

\begin{tabular}{lcccc}
\hline \multirow{2}{*}{ Direction } & \multicolumn{2}{c}{ Right } & \multicolumn{2}{c}{ Left } \\
\cline { 2 - 5 } & $\mathbf{n}$ & $\boldsymbol{\%}$ & $\mathbf{n}$ & $\boldsymbol{\%}$ \\
\hline Horizontal & 4 & 4 & 4 & 4 \\
Vertical & 96 & 96 & 96 & 96 \\
\hline
\end{tabular}

\section{DISCUSSION}

Locating the greater palatine foramen is important clinically when a trigeminal second division block is needed or when posterior palatal anaesthesia is desired. Significant variations in the location of the foramen were seen in this study, and the knowledge of these variations is a must for effective local anaesthesia.

Different authors describe the location of the foramen differently. According to Goss (1973), Hassanali \& Mwaniki (1984) and Snell (1981), the foramen was located in the posterolateral angle of the hard palate. Whereas Frazer (1965), Romanes (1981), Slavkin et al. (1966), and Macintosh \& Ostlere (1955) had cited it opposite the last maxillary molar tooth. Bannister (1989) had reported it near the lateral margin of hard palate behind the palatomaxillary suture, while Sicher \& Dubrul (1980) had reported it close to the posterior margin of the hard palate.

According to Moore (1980) it was medial to the third molar tooth. Robert \& Sowray (1979) had reported it medial to the second and third molars, while Mercuri (1979) had reported it distal to the second molar. Westmoreland \& Blanton (1982) had cited it commonly opposite the third molar (50.7\%). Next common site was between second and third molars (33.7\%). In $9.7 \%$ it was opposite second molar, and in $6 \%$ it was distal to third molar. According to Khatri et al. (1986), the foramen was located opposite the third molar in $56 \%$, behind third molar in $16 \%$, opposite second molar in $14 \%$, and between second and third molars in $14 \%$. In the present study, the foramen was medial to third molar in $87.5 \%$ (Fig 3); between second and third molars in 3.5\%; behind third molar in 8\% (Fig 4); and medial to second molar in $1 \%$ skulls studied.

Distance from Greater palatine foramen to median palatine suture and posterior margin of hard palate: According to Westmoreland \& Blanton, the mean distance measured from the foramen to median palatine suture was $1.5 \mathrm{~cm}$. Khatri et al., reported that the foramen lies $1.57 \mathrm{~cm}$ on the right side and $1.61 \mathrm{~cm}$ on the left side. In the present study, it was $1.67 \mathrm{~cm}$ on the right side and $1.66 \mathrm{~cm}$ on the 
left side in the male skulls. 'Z' test was applied and the difference was found to be insignificant.

According Westmoreland \& Blanton, the mean distance measured from the foramen to posterior palatal margin was $0.19 \mathrm{~cm}$, and according to Khatri et al., the foramen was $0.54 \mathrm{~cm}$ from posterior palatal margin. In the present study, the foramen was $0.69 \mathrm{~cm}$ on the right side and $0.69 \mathrm{~cm}$ on the left side in the male skulls. ' $Z$ ' test was applied and the difference in the distance was found to be insignificant. The distance measured in female skulls from foramen to median palatine suture was $1.62 \mathrm{~cm}$ on right side and $1.64 \mathrm{~cm}$ on left side. ' $\mathrm{Z}$ ' test was applied and the difference in distance was found to be insignificant. The mean distance measured from the foramen to posterior palatal margin was $0.68 \mathrm{~cm}$ and $0.70 \mathrm{~cm}$ on the right and left sides of female skulls respectively. 'Z' test was applied and the difference in the distance was found to be insignificant. ' $\mathrm{Z}$ ' test was also applied for the distance from the right foramen to median palatine suture in the male and female skulls, and the left foramen to median palatine suture in the male and female skulls. The difference in distance was found to be significant on the right side only. ' $Z$ ' test was also applied for the distance from the foramen to posterior palatal margin in the male and female skulls on the right and left sides, and the difference in distance was found to be insignificant.

Direction of Greater palatine foramen: Hassanali \& Mwaniki described that in $74 \%$ cases the foramen opened in oblique direction anteromedially, and in $26 \%$ it opened perpendicularly downward.

According to Westmoreland \& Blanton, the direction of foramen was inferior or vertical in $82 \%$, and anterior or horizontal in $18 \%$. Khatri et al., had reported the direction of the foramen as downward in $72 \%$ cases, and downward \& forward in $28 \%$ of skulls. In the present study, the foramen was found to be directed horizontally (4\% on both right and left sides), and vertically (96\% on both right and left sides).

Longitudinal palatal grooves: These were common feature found bilaterally in all the palates (Fig. 3). The grooves were extensive; $5.5 \%$ showing divisions; $86.5 \%$ had crests along its length. Bennett (1978) states that it will be advantageous to insert the needle and deposit the solution so that the anterior palatine nerve will be anaesthetised anteriorly to the foramen. Clinically, the presence of crests and bridges along the grooves and particularly at the opening of the foramen may present problems in the administration of local anaesthesia.

\section{CONCLUSION}

In the present study, the greater palatine foramen was found to be against the maxillary third molar in most of the skulls $(87.5 \%)$. Locating this foramen, and keeping in mind the distance from the foramen to median palatine suture and posterior palatal margin, is important clinically when a trigeminal second division block is needed or when posterior palatal anaesthesia is desired.

\section{ACKNOWLEDGEMENTS}

Our sincere thanks to the faculty members of our university who helped and supported during the writing of this manuscript.

DAVE, M. R.; YAGAIN, V. K. \& ANADKAT, S. Variaciones anatómicas en la posición del foramen palatino mayor en cráneos humanos adultos y su significación clínica. Int. J. Morphol., 31(2):578-583, 2013.

RESUMEN: El dolor es un síntoma común y preocupante en la práctica dental. Dependiendo de los casos, diferentes técnicas se utilizan para aliviar el dolor. Una de ellas es el bloqueo periférico del nervio trigémino. Esta, ha demostrado ser una forma eficaz y conveniente para anestesiar grandes regiones del complejo oral y maxilofacial. Este bloqueo puede ser intraoral o extraoral. La vía intraoral es a través del foramen palatino mayor en la cual se ingresa en la fosa pterigopalatina, donde se encuentra el nervio maxilar. Las variaciones morfológicas en la posición del foramen palatino mayor puede ser de importancia clínica en la administración de anestesia local y en la cirugía del paladar. En el presente estudio, se examinó la distancia del foramen palatino mayor desde la sutura palatina mediana y el margen posterior del paladar duro, y su posición relativa a los molares superiores, así como la dirección del foramen palatino mayor. maxilares.

PALABRAS CLAVE: Foramen palatino mayor; Bloqueo periférico del nervio trigémino; Fosa pterigopalatina; Molares 
DAVE, M. R.; YAGAIN, V. K. \& ANADKAT, S. A study of the anatomical variations in the position of the greater palatine foramen in adult human skulls and its clinical significance. Int. J. Morphol., 31(2):578-583, 2013

\section{REFERENCES}

Bannister, D. Gray's Anatomy. $38^{\text {th }}$ ed. London, Churchill Livingstone, 1989. p.354.

Bennett, R. C. Monheim's Local Anaesthesia And Pain Control In Dental Practice. $6^{\text {th }}$ ed. St. Louis, C. V. Mosby Company, 1978. p.441.

Frazer, J. Anatomy of Human Skeleton. $6^{\text {th }}$ ed. London, J. \& A. Churchill, 1965. pp.212-3.

Goss, C. M. Gray's Anatomy of Human Body. $29^{\text {th }}$ ed. Philadelphia, Lea \& Febriger, 1973. p.141.

Hassanali, J. \& Mwaniki, D. Palatal Analysis and Osteology of the Hard Palate of the Kenyan African Skulls. Anat. Rec., 209(2):273-80, 1984.

Khatri, K.; Pradhan, S. \& Tuli, A. Disposition of Palatine Foramen. J. Indian Dent. Assoc., 58:177-80, 1986.

Macintosh, R. \& Ostlere, M. Local Analgesia. Head and Neck. Edinburgh, E \& S Livingstone, 1955. p.10.

Mercuri, L. G. Intraoral second division nerve block. Oral Surg. Oral Med. Oral Pathol., 47(2):104-13, 1979.

Moore, K. L. Clinically Oriented Anatomy. Baltimore, Williams \& Wilkins, 1980. p.1004.

Robert, D. H. \& Sowray, J. H. Local Anaesthesia in Dentistry. 2nd ed. London, John Wright, 1979. pp.87-8.

Romanes, G. J. Cunningham's Textbook. $12^{\text {th }}$ ed. Oxford, Oxford University Press, 1981. pp.116-7.

Sicher, H. \& Dubrul, B. L. Oral Anatomy. $7^{\text {th }}$ ed. St. Louis, C. V. Mosby Co., 1980. pp.84-5.

Sinnatamby, C. S. Last's Anatomy Regional And Applied. $10^{\text {th }}$ ed. Edinburgh, Churchill Livingstone, 1999. p.504.

Slavkin, H. C.; Canter, M. R. \& Canter, S. R. An anatomic study of the pterygomaxillary region in the craniums of infants and children. Oral Surg. Oral Med. Oral Pathol., 21(2):225-35, 1966.

Snell, R. S. Clinical Anatomy for Medical Students. 2nd ed. Boston, Little, Brown and Company, 1981. p.672.

Westmoreland, E. E. \& Blanton, P. L. An Analysis of the Variations in the Position of the Greater Palatine Foramen in the Adult Human Skull. Anat. Rec., 204(4):383-8, 1982.

\author{
Correspondence to: \\ Professor of Anatomy \\ GMERS Medical College \\ Valsad \\ Gujarat \\ INDIA
}

Email: miteshdave30@yahoo.com

Received: 01-10-2012

Accepted: 29-01-2013 